\title{
Atasi Limbah Organik Melalui Pelatihan Pembuatan Pupuk Kompos Metode Keranjang Takakura Kepada Kelompok Dawis Cempaka Semarang
}

\author{
Overcoming Organic Waste through Takakura Method Composting Workshop for \\ Dawis Cempaka Semarang Group
}

\author{
Dita Ayu Mayasari ${ }^{1}$, Menik Dwi Kurniatie ${ }^{2}$, Amalia $^{3}$ \\ ${ }^{1}$ Teknik Biomedis, ${ }^{2}$ Teknik Biomedis , ${ }^{3}$ Teknik Industri /Fakultas Teknik/Universitas Dian \\ Nuswantoro \\ E-mail: $\underline{1}$ mayasari.dita@dsn.dinus.ac.id, ${ }^{2}$ nikdwika@dsn.dinus.ac.id,
}

\begin{abstract}
Abstrak
Permasalahan terkait komposisi sampah, pengolahan sampah, pengurangan sampah hingga pencemaran lingkungan seperti ini akan menjadi masalah besar apabila tidak ditangani dengan benar. Permaslahan tersebut dapat diselesaikan dengan solusi untuk menciptakan keadaan lingkungan yang sehat, bersih dan memberikan keuntungan dari sisi ekonomis karena dapat dikelola dengan mudah untuk dijadikan pupuk kompos sebagai pemanfaatan teknologi tepat guna komposter. Pembuatan pupuk kompos dengan metode keranjang Takakura dinilai tepat untuk menyelesaiakan permasalahan sampah mulai dari komposisi, pengolahan, mengurangi dan pemanfaatan sampah. Masalah yang dihadapi kelompok Dawis Cempaka adalah kurangnya informasi dan keterbatasan pengetahuan dari warga setempat, yang belum memahami inovasi bari pembuatan pupuk kompos metode keranjang Takakura dimana metode ini juga sebagai alternatif pembuatan pupuk kompos alami seperti LRB (Lubang Resapan Biopori) dengan kendala keterbatasan lahan sehingga media komposer diganti dengan metode keranjang Takakura. Pengetahuan terkait pemanfaatan sampah rumah tangga bagi ibu-ibu Kleompok Dawis Cempaka semakin berkembang memlalui kegiatan pengabdian Pelatihan Pembuatan Pupuk Kompos dengan Metode Keranjang Takakura. Pembuatan pupuk kompos ini mampu meningkatkan daya inovasi baru dalam pengolahan sampah rumah tangga, meningkatkan produktifitas dibidang pertanian serta ikut turut dalam mengurangi penumpukan sampah organik.
\end{abstract}

Kata kunci: Takakura, kompos

Abstract
Problems related to the composition of waste, waste management, waste reduction to environmental pollution like this will be a big problem if not handled properly. This problem can be solved with a solution to create a healthy, clean environment and provide economic benefits because it can be easily managed to be composted as an appropriate technology for composter utilization. Making compost using the Takakura basket method is considered appropriate to solve waste problems ranging from composition, processing, reducing and utilization of waste. The problem faced by the Dawis Cempaka group is the lack of information and limited knowledge from local residents, who do not yet understand the innovation of making Takakura compost basket method where this method is also an alternative to making natural compost fertilizer such as LRB (Biopori Infiltration Hole) with limited land constraints so that the media the composer was replaced by the Takakura basket method. Knowledge related to the use of household waste for Kleis Dawis Cempaka women is growing through the devotion of the Compost Fertilizer Making Training using the Takakura Basket Method. Making compost is able to increase the power of new innovations in the processing of household waste, increase productivity in agriculture and participate in reducing the accumulation of organic waste 
Keywords: Takakura, compost

\section{PENDAHULUAN}

Berdasarkan data di tempat pembuangan akhir (TPA) Jatibarang Kota Semarang, jumlah sampah yang masuk ke TPA Jatibarang (2017) berkisar antara 800-900 ton per hari dengan komposisi sampah $62 \%$ sampah organic dan sisanya sampah non-organik. TPA Jatibarang memiliki fasilitas pengomposan oleh PT. Narpati dengan kapasitas 350 ton per hari [1]. Fasilitas pengomposan yang dimiliki oleh TPA Jatibarang tidak dapat melakukan pengomposan terhadap sampah yang datang setiap harinya, dimana sampah organik yang harus dikomposkan setidaknya 500 ton per hari. Hal ini tentunya akan menyebabkan penumpukan sampah kedepannya.

Penanganan sampah tidak seharusnya dibebankan kepada pihak-pihak yang berhubungan dengan pemerintahan saja, namun dengan mengadakan sosialisai tentang sampah bisa menumbuhkan kesadaran dan kepedulian bahwa permasalahan sampah dapat di kurangi mulai dari lingkungan terkecil yaitu rumah tangga.

Salah satu cara yang dapat digunakan untuk meminimalkan dampak negatif yang ditimbulkan sampah organik domestk adalah mengolah sampah tersebut dengan melibatkan masyarakat. Upaya pengolahan sampah berbasis masyarakat mandiri perlu diakukan, mulai dari tahap pengumpulan hingga pemrosesan akhir [2]. Penanganan sampah dengan metode pengkomposon bahan sampah di tingkatan rumah tangga menjadi jalan keluar terbaik. Mengingat dalam pembuatan kompos skala rumah tangga tidak memerlukan lahan yang luas dan tidak menghasilkan bau tak sedap. Salah satu metode pembuatan kompos yang sederhana, praktis, dan dapat diterapkan untuk skala rumah tangga adalah metode Takakura, yang dapat diaplikasikan dalam skala individu atau rumah tangga. Selain sederhana dan relatif murah, metode komposting Takakura tepat untuk diaplikasikan dalam skala rumah tangga karena tidak membutuhkan lahan yang luas, portable, proses dekomposisi yang cepat, dan tidak berbau [3].

Metode Takakura merupakan metode komposting yang diperkenalkan di Indonesia oleh Mr. Takakura pada tahun 2004. Metode ini terbukti dapat mengolah 1,5kg sampah organik per hari tanpa menimbulkan aroma tidak sedap. Jenis sampah rumah tangga yang dapat diolah dengan metode ini adalah sisa sayuran, sisa nasi, sisa ikan, dan sampah organik lainnya. Sebelum sampah dapat dimanfaatkan, perlu terlebih dahulu digolongkan/dipisahkan antara sampah yang bisa didaur ulang seperti sampah organik yang sebagian besaar berasal dari sampah rumah tangga. Metode ini memanfaatkan proses fermentasi yang melibatkan bakteri aerobik [4]. Kompos yang dibuat dengan menggunakan Metode Takakura terbukti memiliki makronutrien yang paling diperlukan yaitu $\mathrm{N}, \mathrm{P}, \mathrm{K}$ dan rasio $\mathrm{C} / \mathrm{N}$ dengan kadar optimal. Selain makronutrien, kompos yang dibuat dengan Metode Takakura memiliki kandungan mikronutrien $\mathrm{Fe}$ dan $\mathrm{Mn}$ dengan kadar mencapai $1.181+177 \mathrm{mg} / \mathrm{kg}$ dan $327+49 \mathrm{mg} / \mathrm{kg}$. Kandungan logam berat berupa $\mathrm{Cu}$ dan $\mathrm{Zn}$ juga ditemukan pada kompos yang dihasilkan dengan Metode Takakura, namun masih dalam kadar yang kecil dan masih memenuhi standard sehingga masih tergolong aman untuk lingkungan [5].

Metode Takakura terbukti dapat menyelesaikan permasalahan sampah di lingkungan rumah tangga, hanya saja permasalahan yang terjadi pada kelompok Dawis Cempaka yang terletak di Kecamatan Semarang ini adalah kurangnya informasi warga terkait bagaimana cara penanganan sampah yang benar, mulai dari penggolongan, pengolahan, pengurangan dan dampak pencemaran sampah menyebabkan masyarakat cenderung beranggapan bahwa sampah adalah barang yang harus dibuang dan tidak bisa dimanfaatkan kembali. Kegiatan pengabdian ini dilakukan sebagai bentuk dukungan dan kepedulian terhadap meningkatnya sampah organik yang sebagaian besar berasal dari sampah rumah tangga yaitu berupa sisa-sisa makanan. Pelatihan ini juga bertujuan untuk mengurangi penumpukan sampah yang terjadi melalui pengelolaan mandiri. Secara garis besar, alur ini dapat dirangkum menjadi kerangka berpikir seperti yang terdapat pada Gambar 1 . 


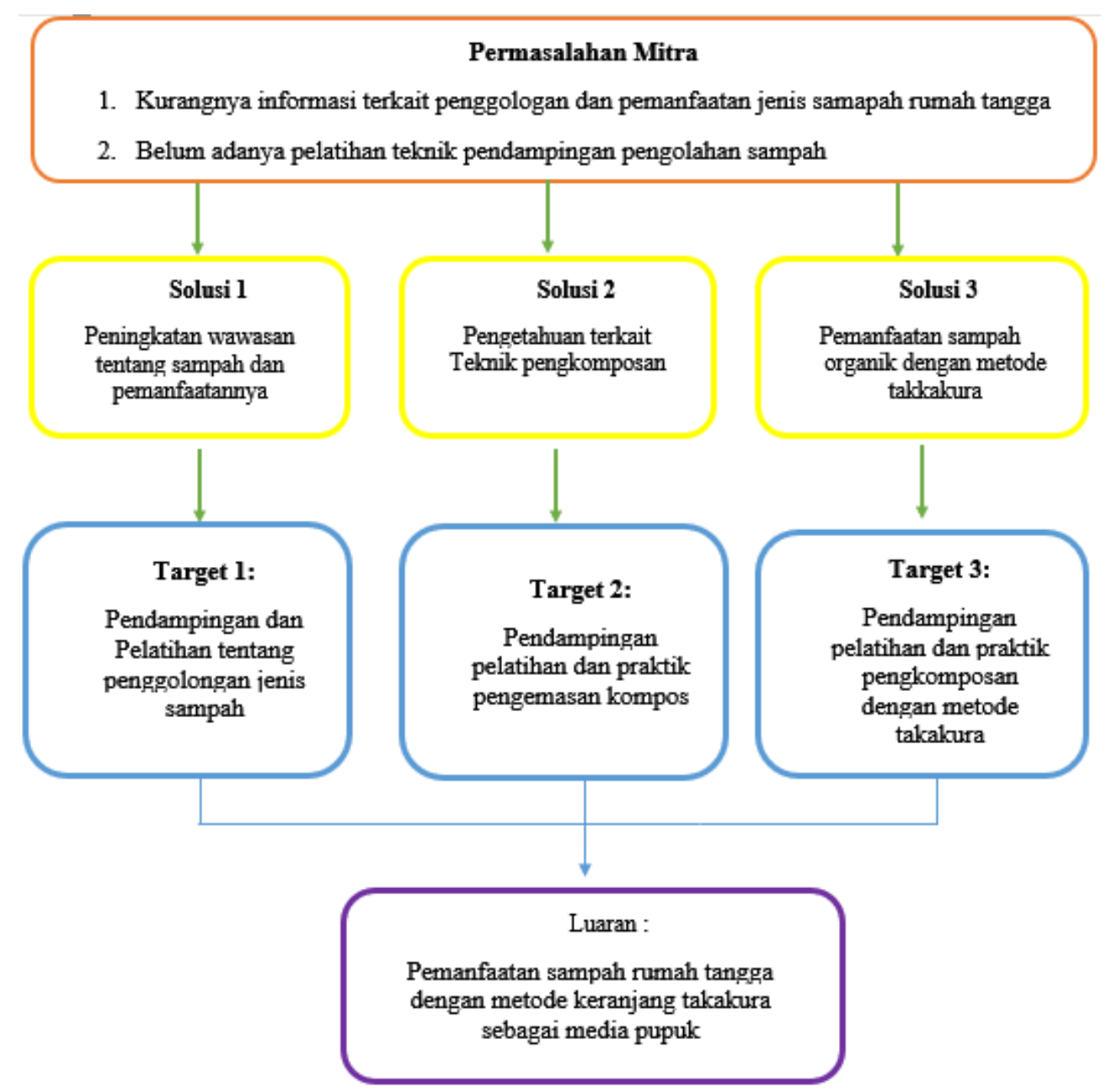

Gambar 1. Kerangka Kegiatan Pengabdian

\section{METODE PELAKSANAAN}

Kegiatan ini dilakukan di Kelurahan Purwoyoso, Kecamatan Ngaliyan, Kota Semarang. Peserta dari kegiatan ini adalah ibu-ibu kelompok Dasa Wisma Cempaka dari RT 03 RW 06. Ibu-ibu yang mengikuti kegiatan ini berjumlah 19 orang. Adapun latar belakang peserta adalah sebagai ibu rumah tangga. Pelaksanaan kegiatan ini terbagi menjadi tiga tahapan yaitu tahap persiapan, tahan pelatihan dan tahap evaluasi.

Tahapan persiapan merupakan tahapan dimana tim menyiapkan segala material yang diperlukan dalam kegiatan pelatihan. Kegiatan pengabdian diawali dengan persiapan pembelian alat dan bahan yang dibutuhkan selama kegiatan pengabdian pada tanggal 8 Desember 2019 . persiapan alat bahan selama kegiatan pengabdian berlangsung yaitu persiapan pembuatan bakteri cair dan pembuatan keranjang Takakura. Bahan-bahan untuk pembuatan bakteri cair meliputi tape, tempe, yakult dan gula. Cara pembuatan bakteri cair adalah dengan mencampur Tape dan tempe menjadi satu kemudian dimasukkan ke dalam $5 \mathrm{~L}$ air gula dan ditambahkan satu botol yakult. Larutan ini ditempatkan dalam galon untuk kemudian difermentasi selama tujuh hari. Tape dan tempe yang awalnya tenggelam lama-lama akan mengapung dan plastik yang digunakan sebagai tutup galon akan mengembang (Gambar 3.2). Hal ini menunjukkan bahwa proses fermentasi dalam pembuatan bakteri cair telah berhasil. 
Pada tanggal 21 Desember 2019 dilakukan pembelian material keranjang takakura berupa keranjang berpori, kardus, tali rafia, kain hitam, kain strimin dan sekam. Kardus dilapiskan dalam keranjang berpori dan diikatkan ke keranjang menggunakan tali rafia. Kain strimin dipotong sesuai ukuran dasar dan atas keranjang kemudian dijahit sehingga dapat diisi dengan sekam dan menjadi bantalan sekam (Gambar 2 dan 3).

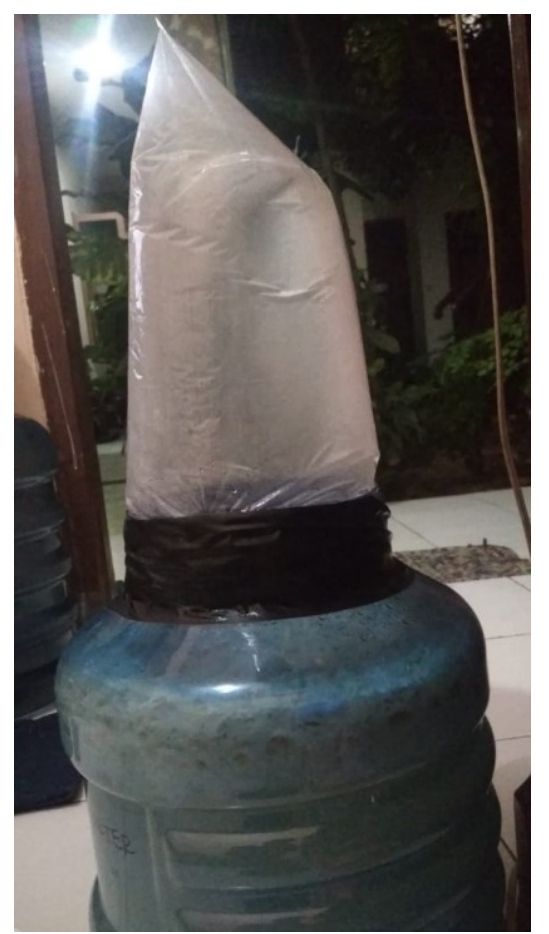

Gambar 2. Galon berisi bakteri cair dengan tutup plastik yang mengembang
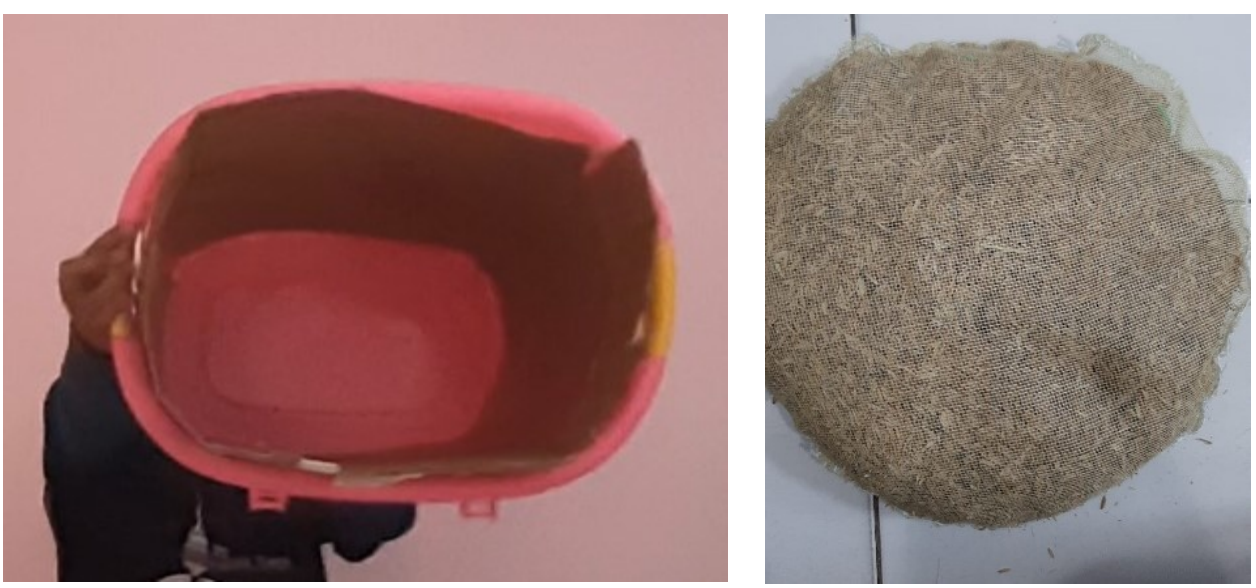

Gambar 3 Keranjang Takakura dan bantalan sekam 


\section{HASIL DAN PEMBAHASAN}

Kegiatan ini dilakukan oleh sebuah tim yang beranggotakan tiga orang dosen di lingkungan Fakultas Teknik Universitas Dian Nuswantoro. Tim yang terlibat dalam kegiatan pengabdian masyarakat ini antara lain: Dita Ayu Mayasari S.T., M.Eng. sebagai dosen Teknik Biomedis yang akan menjelaskan tentang langka-langakah pembuatan kompos dengan metode takakura. Amalia, M.T. sebagai dosen Teknik Industri yang akan menjelaskan tentang pengetahuan penggolongan jenis sampah dan cara-cara pemanfaatan sampah rumah tangga. Menik Dwi Kurniatie, S.Si., M.Biotech. sebagai dosen Teknik Biiomedis yang akan menjelaskan mengenai mekanisme pengkomposan sampah organik dan teknik perawatan kompos di dalam keranjang Takakura.

Kegiatan pelatihan dilakukan pada tanggal 12 Januari 2020 di kediaman pimpinan Kelompok Dawis Cempaka, Purwoyoso, Ngaliyan, Semarang. Kegiatan dimulai dari jam 08.00 dengan melakukan persiapan di lokasi pelatihan. Kegiatan pelatihan dihadiri oleh 13 anggota ibu-ibu Kelompok Dawis Cempaka. Pelatihan dibuka oleh Ketua Dawis Cempaka dan dilanjutkan dengan pemberian materi oleh tim. Selama berlangsungnya pelatihan oleh tim Pengabdian, ibu-ibu kelompok Dawis Cempaka juga diberi kesempatan langsung mempraktikan cara menempatkan bagian sekam, potongan sayur dalam keranjang Takakura. Kegiatan ini ditutup dengan sesi foto bersama dan serah terima keranjang takakura dan tanaman sayur untuk digunakan di masing-masing rumah peserta.

Pada tanggal 24 Januari 2020 dilakukan kunjungan monitoring terkait pembuatan bakteri cair secara mandiri oleh ibu-ibu kelompok dawis. Berdasarkan hasil kunjungan tersebut didapatkan temuan bahwa teknik yang digunakan untuk menutup wadah dengan menggunakan plastic kurang tepat sehingga proses fermentasi tidak berjalan dengan sempurna sehingga dilakukan evaluasi kembali. Pendampingan juga dilakukan melalui media komunikasi berupa whatsapp. Setelah pembuatan bakteri cair secara mandiri berhasil, ibu-ibu kelompok dawis mencoba membuat campuran sekam, dedak dan bakteri cair sendiri untuk kemudian dimasukkan kedalam keranjang takakura.

Pada tanggal 22 Februari 2020 dilakukan kunjungan monitoring kembali terkait keranjang takakura yang digunakan. Berdasarkan kunjungan tersebut didapatkan temuan bahwa terdapat satu keranjang yang dibuat saat pelatihan pengomposan tidak terjadi dengan baik. Tidak timbul suhu hangat di sekitar keranjang pada pagi hari dan timbul bau apek. Kemudian satu keranjang lagi pengomposan tidak terjadi akibat kondisi sampah dan sekam didalzam keranjang terlalu kering

\section{KESIMPULAN DAN SARAN}

Pengetahuan terkait pemanfaatan sampah rumah tangga bagi ibu-ibu Kleompok Dawis Cempaka semakin berkembang memlalui kegiatan pengabdian Pelatihan Pembuatan Pupuk Kompos dengan Metode Keranjang Takakura

\section{UCAPAN TERIMA KASIH}

Ucapan terimakasih ditujukan kepada donator dana pengabdian yaitu Lembaga Penelitian dan Pengabdian Masyarakat (LP2M) Uiversiats Dian Nuswantoro yang senantiasa mendukung kelancaran pelaksanaan kegiatan pengabdian ini dan berbagai pihak yang sangat krusial dalam proses berlangsungnya kegatan pengabdian ini. 


\section{DAFTAR PUSTAKA}

[1] https://mediaindonesia.com/read/detail/218302-persoalan-sampah-tanggung-jawab-kita, di akses tgl 9 Oktober 2019

[2] https://mediaindonesia.com/read/detail/218302-persoalan-sampah-tanggung-jawab-kita, di akses tgl 9 Oktober 2019

[3] Hakim,N., dkk, “ Pelatihan Pembuatan Kompos Organik Metode Keranjang Takakura sebagai Solusi Penangan Sampah di Lingkungan Kost Mahasiswa, Jurnal Pengabdian Masyrakat, Vol.1, No.1 Jaunuari-Junin 2019.

[4] Warjoto, R.E., “ Metode Komposting Takakura untuk Pengolahan Sampah Organik Rumah Tangga di Cisauk, Tangerang “, UKI Atmajaya, 2017.

[5] Jimenez-Antillon, Joaquin et al. "Food Waste Recovery with Takakura Portable Compost Boxes in Offices and Working Places"2018 